\title{
Single-Tube Flow Cytometry Assay for the Detection of Mature Lymphoid Neoplasms in Paucicellular Samples
}

\author{
Alessandra Stacchini ${ }^{a} \quad$ Anna Demurtas $^{a}$ Sabrina Aliberti ${ }^{a} \quad$ Antonella Barreca $^{c}$ \\ Domenico Novero $^{b}$ Donatella Pacchioni ${ }^{b}$ \\ ${ }^{a}$ Flow Cytometry Unit at ${ }^{b}$ Anatomic Pathology, Città della Salute e della Scienza, and ${ }^{\mathrm{c} C a n d i o l o ~ C a n c e r ~}$ \\ Institute-FPO-IRCCS, Turin, Italy
}

\section{Key Words}

Multicolor flow cytometry · Paucicellular samples .

Non-Hodgkin lymphomas

\section{Abstract}

Objectives: Flow cytometry (FC) has become a useful support for cytomorphologic evaluation (CM) of fine-needle aspirates (FNA) and serous cavity effusions (SCE) in cases of suspected non-Hodgkin lymphoma (NHL). FC results may be hampered by the scarce viability and low cellularity of the specimens. Study Design: We developed a single-tube FC assay (STA) that included 10 antibodies cocktailed in 8-color labeling, a cell viability dye, and a logical gating strategy to detect NHL in hypocellular samples. The results were correlated with $\mathrm{CM}$ and confirmed by histologic or molecular data when available. Results: Using the STA, we detected B-type $\mathrm{NHL}$ in 31 out of 103 hypocellular samples (81 FNA and 22 $\mathrm{SCE})$. Of these, 8 were not confirmed by $\mathrm{CM}$ and 2 were considered to be only suspicious. The FC-negative samples had a final diagnosis of benign/reactive process (42/72), carcinoma (27/72), or Hodgkin lymphoma (3/72). Conclusions: The STA approach allowed obtainment of maximum immuno- phenotyping data in specimens containing a low number of cells and a large amount of debris. The information obtained by STA can help cytomorphologists not only to recognize but also to exclude malignant lymphomas.

(c) 2016 S. Karger AG, Basel

\section{Introduction}

Several studies have demonstrated the usefulness of flow cytometry (FC) in the diagnosis of non-Hodgkin lymphoma (NHL) in samples such as fine-needle aspirates (FNA), cerebrospinal fluid, vitreous biopsies, and serous cavity effusions (SCE), in which cytomorphology evaluation (CM) may be insufficient to detect neoplastic involvement [1-10]. Multiparameter FC analysis, which makes it possible to obtain reliable information about cellular composition, immunophenotype, and lymphocyte cell size, could help reduce the overall number of inconclusive results that may be obtained by evaluation of specimens based on morphology alone. FC investigations may, however, be hindered by the low cell number, limiting the number of tests that can be performed. Tailored

\section{KARGER}

E-Mail karger@karger.com www.karger.com/acy
(C) 2016 S. Karger AG, Basel

0001-5547/16/0604-0385\$39.50/0
Correspondence to: Dr. Alessandra Stacchini

Anatomia ed Istologia Patologica $1 \mathrm{U}$

Città della Salute e della Scienza - Presidio Molinette

Via Santena 7, IT-10126 Turin (Italy)

E-Mail astacchini@cittadellasalute.to.it 
panels and appropriate sample processing are mandatory in such cases [11]. This study reports our experience with paucicellular samples using an FC approach that employs a nuclear dye to recognize viable cells, antibodies cocktailed in 8-color labeling to detect lymphomas, and a Boolean gating strategy to analyze data.

\section{Patients and Methods}

Between December 2011 and December 2015, FNA ( $\mathrm{n}=674)$ and SCE $(n=264)$ samples were sent for FC evaluation.

Among 938 specimens, 103 (10.9\%) belonging to 96 patients (mean age 59 years, range 17-92) were considered hypocellular (cellularity $<0.5 \times 10^{6}$ total cells) and were selected for evaluation with a single-tube FC assay (STA). This study was approved by the local institutional review board. Informed consent was obtained from all participants. The STA was applied to 40 FNA (29 lymph nodes and 11 extranodal lesions), 41 endoscopic ultrasound (EUS)-FNA (13 deep lymph nodes, 27 extranodal lesions, and 1 pancreatic cyst fluid), and 22 SCE (15 pleural fluids, 5 ascites, and 2 pericardial fluids). FNA were placed in Vacutainer lithium heparin tubes (BD Biosciences, San Jose, Calif., USA) containing RPMI 1640 with $10 \%$ fetal calf serum (holding medium); fluids were collected directly into Vacutainer lithium heparin tubes. All detailed procedures for FNA collection and cell processing have been previously published $[4,11]$.

The STA used the following monoclonal antibody (MoAb) combinations:

- for samples evaluated between 2011 and 2014 (74 specimens): $(\kappa+\mathrm{CD} 8)$ fluorescein isothiocyanate (FITC) $/(\lambda+\mathrm{CD} 4)$ phycoerythrin (PE)/7-aminoactinomycin D (7-AAD)/CD10 phycoerythrin-cyanin7 (PE-cy7)/CD5 allophycocyanin (APC)/ (CD19+CD20) APC-H7/CD3 Horizon V450 (HV450)/CD45 Horizon V500 (HV500 ); all MoAbs were from BD Biosciences; 7-AAD was from Beckman Coulter, Marseille, France.

- for samples evaluated in 2015 (29 specimens): ( $\kappa+C D 8)$ FITC/ $(\lambda+\mathrm{CD} 4) \mathrm{PE} / 7-\mathrm{AAD} /(\mathrm{CD} 19+\mathrm{CD} 20) \mathrm{PE}-\mathrm{cy} 7 / \mathrm{CD} 10 \mathrm{APC} / \mathrm{CD} 3$ allophycocyanin-Alexa Fluor 750 (APC-A750)/CD5 Pacific Blue (PB)/CD45 Krome Orange (KrO); $\kappa$ and $\lambda$ were from $\mathrm{BD}$ Biosciences; the remaining MoAbs were all from Beckman Coulter.

All antibodies were previously titered for optimal staining. After washing and resuspension, the samples were immediately acquired on FACSCanto II cytometers (BD Biosciences; configured with 3 lasers to detect up to 8 colors and analyzed with Diva software) for specimens evaluated between 2011 and 2014, or on Navios cytometers (Beckman Coulter; configured with 3 lasers to detect up to 10 colors and analyzed with Kaluza software) for specimens evaluated in 2015. The instrument fluidic was accurately washed prior to sample acquisition to minimize the risk of carryover and/ or false-positive events; ungated flow-cytometric runs were continued to achieve maximum cellular acquisition, leaving no residual fluid in the collection tube. Cytometer performance was tested by applying daily quality control protocols as per the manufacturer's instructions. Verification of the compensation matrix was performed by analyzing normal peripheral blood cells labeled with CD8 in different fluorochrome conjugations depending on the instrument used for acquisition.
Viability assessment was made by FC using a 7-AAD dye that intercalates into double-stranded nucleic acids, employed to distinguish between viable cells (7-AAD negative) and apoptotic cells (7-AAD dimly positive) or late apoptotic-dead cells (7-AAD brightly positive) [12]. Viable cells were analyzed in a forward scatter (FS) versus a 7-AAD dot plot and, to accurately and reproducibly set the gate, the fluorescence intensity value of the control samples was considered. Cell suspensions from reactive lymph nodes with a cell viability $\geq 95 \%$, determined by Trypan Blue exclusion, served as control samples. To obtain objective and reproducible information about the size of B lymphocytes, the FS signal distribution of $\mathrm{B}$ cells was expressed as a ratio (FSr), with the FS distribution obtained for $\mathrm{T}$ cells kept as an internal reference. The FSr was previously determined in the laboratory in reactive lymphadenopathy and NHL to be $\leq 1$ for small cells, between 1.1 and 1.29 for medium cells, and $\geq 1.3$ for large cells (all NHL used for the calculation of FSr had a histologic diagnosis). Samples were considered positive for lymphoma when a discrete population of cells, with phenotypic characteristics of a disease entity, was identified [13]. FC data were independently interpreted by the authors (A.S., A.D., and S.A.) blinded to the cytomorphology findings. All detailed procedures for the cytomorphologic analysis of FNA have been previously described [4]. In the case of effusions, fresh specimens were centrifuged at 2,000 rpm for $10 \mathrm{~min}$. Two to 4 drops of the sediment were used for the preparation of 1 Papanicolaoustained slide and $1 \mathrm{H} \& \mathrm{E}$-stained slide. The resulting cell pellet was fixed in a test tube containing $95 \%$ alcohol for the subsequent preparation of cell blocks.

\section{Statistical Methods}

Median values were calculated for the quantitative variables. The Mann-Whitney $U$ test was used to analyze the values of viable cells in EUS-FNA versus FNA and versus BF, as well as the values of lymphocytes [total; T, B, and (natural killer) NK cells, and $\mathrm{CD} 4 / \mathrm{CD} 8$ ratio] in NHL versus benign/reactive processes $(\mathrm{B} / \mathrm{R})$ and versus carcinoma $(\mathrm{Ca})$ samples. $\mathrm{p} \leq 0.05$ was considered statistically significant.

Fig. 1. Example of the STA and gating strategy applied to FNA in a follicular lymphoma (case 11) acquired on a FACSCanto II flow cytometer (BD Biosciences). 7-AAD-negative cells (orange) were gated in order to exclude dead cells. $\mathrm{FSC}-\mathrm{W}^{\text {low }} / \mathrm{CD} 45^{+}$events were gated to define the leukocyte area and to exclude glued cells (doublets; green). Gated cells were examined in the SSC/CD45 diagram for the identification of lymphocyte clusters (gray). A region drawn on $(\mathrm{CD} 19+\mathrm{CD} 20)^{+} / \mathrm{CD}^{-}$events identified the $\mathrm{B}$ cells (blue) and allowed the analysis of surface light chains and CD5 and $\mathrm{CD} 10$ expression on B lymphocytes. A region drawn on $\mathrm{CD}^{+} /$ $(\mathrm{CD} 19+\mathrm{CD} 20)^{-}$events identified T cells (purple) and allowed the quantification of CD4 and CD8 subpopulations and CD5 expression. $\mathrm{CD}^{-} /(\mathrm{CD} 19+\mathrm{CD} 2)^{-}$events (non-T/non-B) were considered to be NK cells. The ratio of FSC-A signal distribution between $\mathrm{B}$ and $\mathrm{T}$ lymphocytes was used to evaluate B-cell size. Population hierarchy (bottom right). Gating on B cells displayed polyclonal and surface light chain-negative elements corresponding to $\mathrm{CD} 10^{+}$ events (red; $25 \%$ of the total lymphocytes). FSC-A = Forward-scatter area; FSC-W = forward-scatter width; SSC-A = side-scatter area.

(For figure see next page.) 

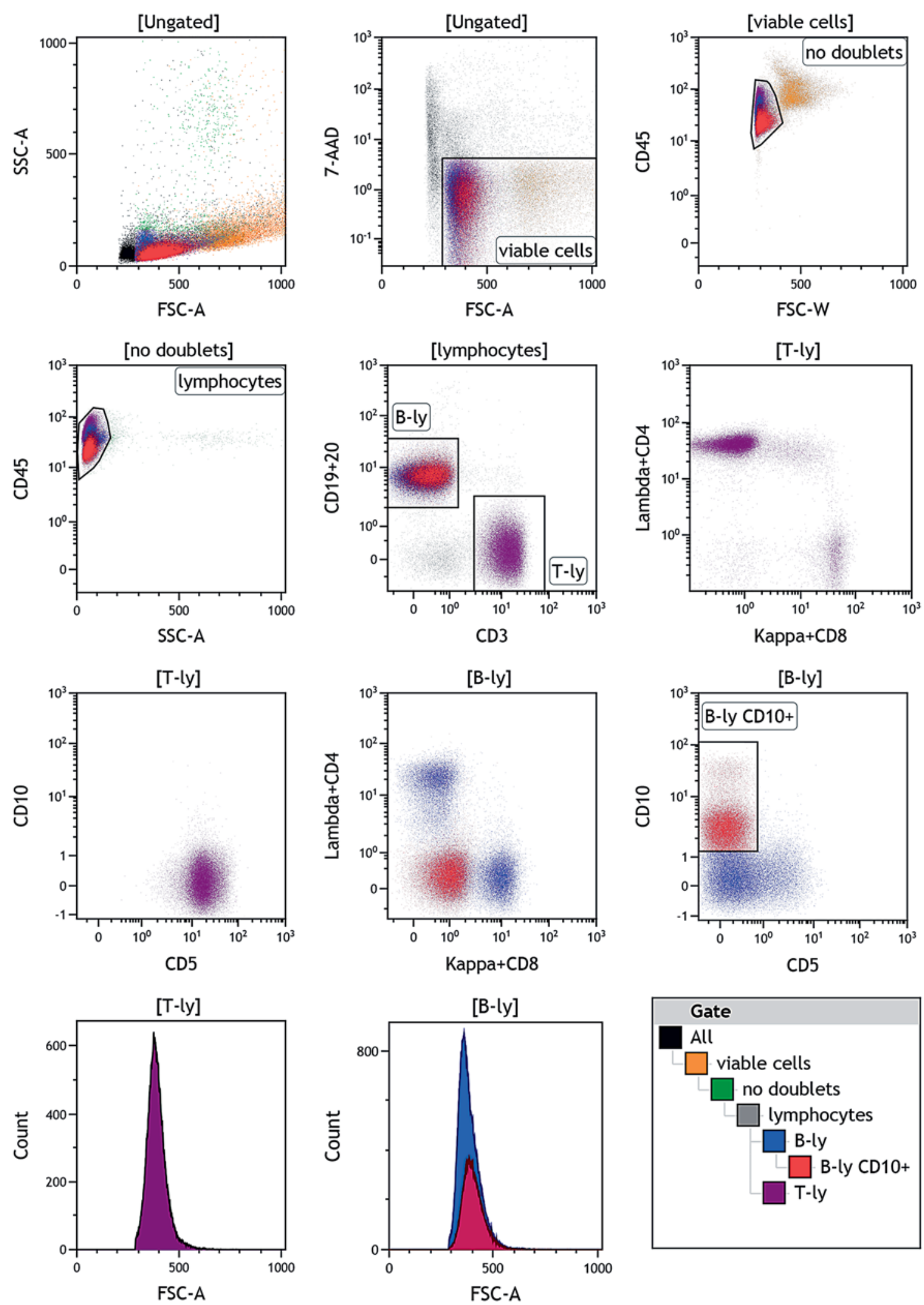

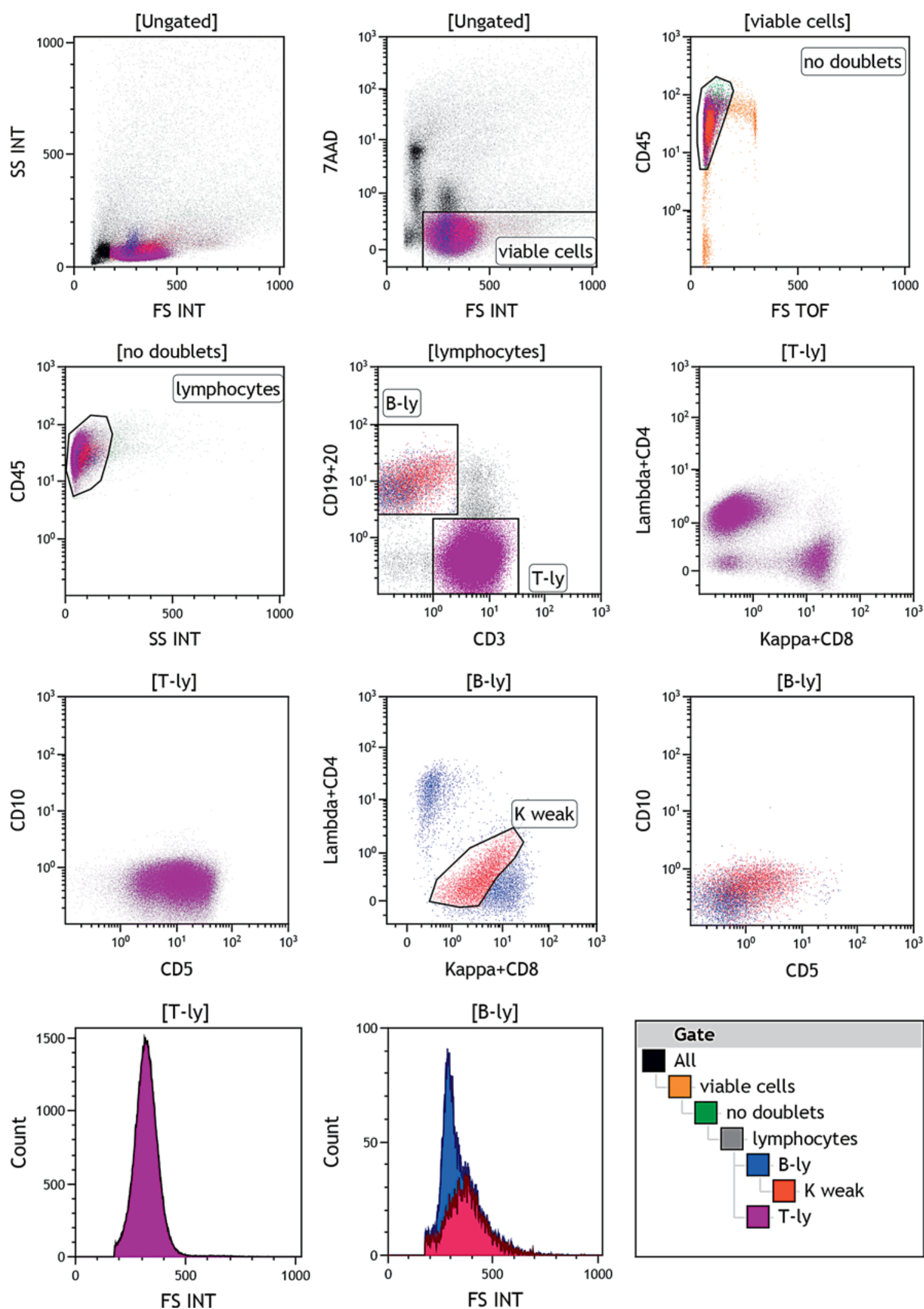

2

(For legend see next page.) 
Table 1. Summary of the parameters analyzed in the 103 samples

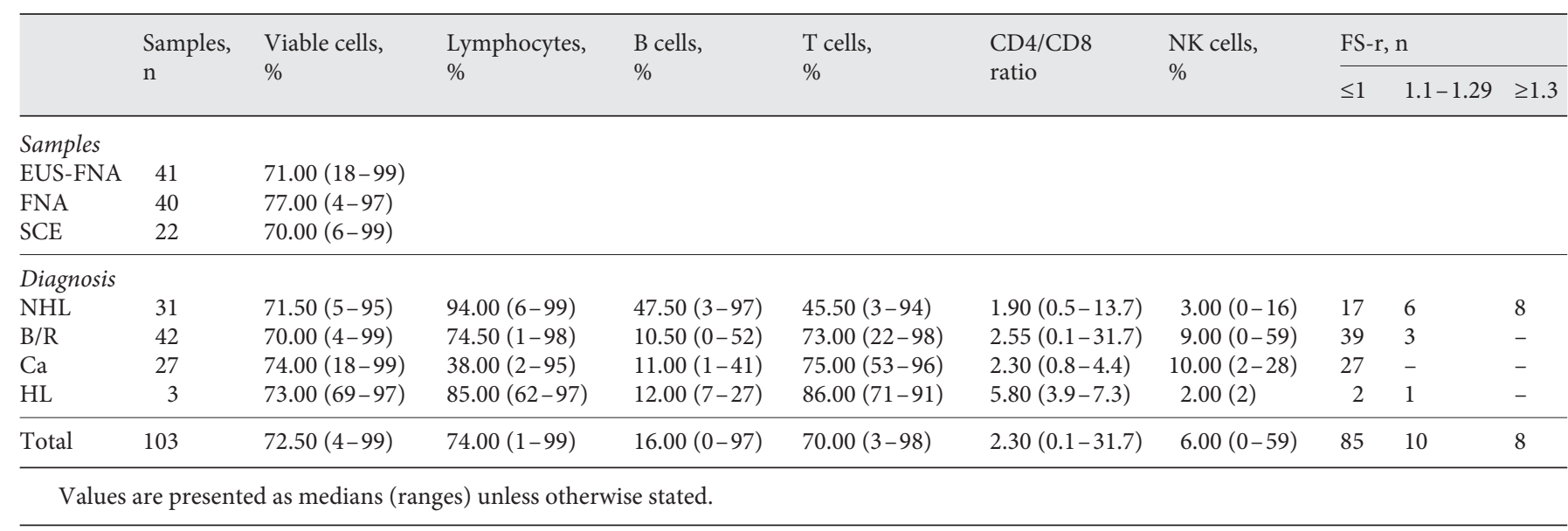

\section{Results}

The overall rationale of the analysis and of the gating strategy applied has been previously published [11]. Examples of the STA protocol with the different cytometers utilized in this study are showed in figures 1 and 2 .

A total of 31 out of $103(30 \%)$ samples positive for lymphoma were detected by FC; 72 out of 103 (70\%) samples were considered negative by FC and were classified as $\mathrm{B} / \mathrm{R}$ $(\mathrm{n}=42), \mathrm{Ca}(\mathrm{n}=21$ of 27$)$, or Hodgkin lymphoma (HL; $\mathrm{n}=1$ of 3 ) by CM; $6 \mathrm{Ca}$ and $2 \mathrm{HL}$ had subsequent histologic confirmation. Of note, FC signaled the presence of CD45-negative cells, not belonging to a hematopoietic lineage, in 5 patients who had a final diagnosis of $\mathrm{Ca}$. A summary of the parameters analyzed for each sample type is reported in table 1. A comparison of the different variables among groups is reported in table 2; no comparison was attempted with HL due to low numbers. The percentage of viable cells ranged from 4 to $99 \%$ of the total cells recovered, with no statistically significant difference among the groups. The total lymphocyte number was significantly higher in NHL compared to B/R and Ca. Given that all NHL detected were of the B-cell type, this group

Fig. 2. Example of the STA and gating strategy applied to an FNA (rectum lesion) in a marginal-zone lymphoma (case 27) acquired on a Navios flow cytometer (Beckman Coulter). The STA and gating strategy described in figure 1 allowed the detection of a small cluster of $\kappa^{\text {weak }}$-positive B cells, consisting of $2.5 \%$ of the total lymphocytes. FS INT = Forward-scatter integral; FS TOF = forwardscatter time of flight; SS INT = side-scatter integral.

FC in Paucicellular Samples had the highest percentage of B cells and the lowest percentage of T cells. No lymphomas of the T-cell type were detected in this study. Between $\mathrm{B} / \mathrm{R}$ and $\mathrm{Ca}$, a significant difference was observed regarding the total lymphocyte number, but no significant differences were measured among lymphocyte subsets. No significant differences in $\mathrm{CD} 4 / \mathrm{CD} 8$ ratio were observed in any comparison.

A summary of the findings in FC-positive specimens is reported in table 3 . Viable cells represented less than $50 \%$ of the total cellularity in 7 specimens. Neoplastic B cells comprised less than $30 \%$ of the total lymphocytes recovered in 15 samples. B-cell size, evaluated based on the normalized FSr, was $<1.3$ in all samples belonging to low-grade lymphoma cases. The normalized FSr was $\geq 1.3$ in 7 high-grade lymphoma cases and in Mantle cell lymphoma (MCL); only sample 30, i.e. a pericardial fluid belonging to a patient with a diagnosis of diffuse large B-cell lymphoma (DLBCL) in the pharynx, displayed an FSr $<1.3$.

CM was unable to detect lymphoma cells in 8 out of 31 (25.8\%) samples considered positive by FC, and 2 out of 31 were considered only suspicious for NHL. Samples 1 and 14 displayed a high level of necrosis, with only isolated small lymphocytes. Sample $2 \mathrm{~b}$ belonged to a patient with an MCL evaluated via analysis of 4 specimens taken from different sites. Results were concordant in FC and CM investigations on EUS-FNA biopsy of gastric mucosa of the body/antrum and fundus (both negative for lymphoma) and on ileum mucosa (positive for lymphoma). The discordant result concerned the EUS-FNA sample of duodenum mucosa, in which FC provided a clearly positive result while CM was able to detect only a small lym- 
Table 2. Comparison of data obtained among the groups

\begin{tabular}{|c|c|c|c|c|c|c|c|c|}
\hline & Samples, n & Group & Viable cells & Lymphocytes & B cells & $\mathrm{T}$ cells & NK cells & CD4/CD8 ratio \\
\hline \multicolumn{9}{|l|}{ Sample } \\
\hline EUS-FNA & 41 & A & A vs. B: 0.93 & - & - & - & - & - \\
\hline FNA & 40 & B & A vs. C: 0.95 & - & - & - & - & - \\
\hline \multicolumn{9}{|l|}{ Diagnosis } \\
\hline NHL & 31 & $\mathrm{D}$ & - & D vs. E: 0.0002 & D vs. E: 0.0001 & D vs. E: 0.0001 & D vs. E: 0.0002 & D vs. E: 0.98 \\
\hline
\end{tabular}

Table 3. Summary of the findings in the FC-positive samples

\begin{tabular}{|c|c|c|c|c|c|c|c|c|c|c|}
\hline $\begin{array}{l}\text { Case } \\
\text { No. }\end{array}$ & Stage & Sample & $\begin{array}{l}\text { Viable cells, } \\
\%\end{array}$ & $\begin{array}{l}\text { Lymphocytes, } \\
\%\end{array}$ & $\begin{array}{l}\text { B cells/ } \\
\text { clonal cells, \% }\end{array}$ & $\mathrm{FSr}$ & $\mathrm{FC}$ & $\mathrm{CM}$ & $\begin{array}{l}\text { Histological or } \\
\text { molecular data }\end{array}$ & $\begin{array}{l}\text { Final } \\
\text { diagnosis }\end{array}$ \\
\hline 1 & $\mathrm{R}$ & EUS-FNA pelvic lymph node & 75 & 96 & $97 / 97$ & $<1$ & $(\mathrm{CD} 19+\mathrm{CD} 20)+/ \mathrm{CD} 5+/ \lambda+$ & $\mathrm{CM}-$ & ND & SLL \\
\hline 2 & $\mathrm{~N}$ & EUS-FNA ileum & 62 & 96 & $66 / 66$ & 1 & $(\mathrm{CD} 19+\mathrm{CD} 20)+/ \mathrm{CD} 5+/ \lambda+$ & $\mathrm{CM}+$ & $\mathrm{FB}$ & MCL \\
\hline $2 b$ & $\mathrm{~N}$ & EUS-FNA duodenum & 31 & 95 & $47 / 47$ & $<1$ & $(\mathrm{CD} 19+\mathrm{CD} 20)+/ \mathrm{CD} 5+/ \lambda+$ & $\mathrm{CM}-$ & ЕБ & MICL \\
\hline 3 & $\mathrm{R}$ & EUS-FNA lung & 88 & 30 & $29 / 29$ & 1.2 & $(\mathrm{CD} 19+\mathrm{CD} 20)+/$ Igs- & $\mathrm{CM}+$ & ND & MALT \\
\hline 4 & $\mathrm{R}$ & EUS-FNA pancreatic lymph node & 84 & 81 & $62 / 62$ & $<1$ & $(\mathrm{CD} 19+\mathrm{CD} 20)+/ \mathrm{CD} 5+/ \lambda+$ & $\mathrm{CM}+$ & ND & SLL \\
\hline 5 & $\mathrm{~N}$ & EUS-FNA adrenal gland & 98 & 96 & $77 / 77$ & 1.1 & $(\mathrm{CD} 19+\mathrm{CD} 20)+/ \kappa+$ & $\mathrm{CM}+$ & $\mathrm{EB}$ & MALT \\
\hline 6 & $\mathrm{~N}$ & FNA laterocervical lymph node & 96 & 97 & $17 / 6$ & 1.7 & $(\mathrm{CD} 19+\mathrm{CD} 20)+/ \kappa+$ & $\mathrm{CM}+$ & EB & TCRBCL \\
\hline 7 & $\mathrm{R}$ & FNA hepatic & 87 & 99 & $57 / 57$ & 1 & $(\mathrm{CD} 19+\mathrm{CD} 20)+/ \mathrm{CD} 5+/ \lambda+$ & $\mathrm{CM}+$ & ND & SLL \\
\hline 8 & $\mathrm{~N}$ & FNA laterocervical lymph node & 18 & 75 & $21 / 21$ & 1.2 & $(\mathrm{CD} 19+\mathrm{CD} 20)+/ \mathrm{CD} 10+/ \kappa+$ & $\mathrm{CM}+$ & EB & FL \\
\hline 9 & $\mathrm{~N}$ & Ascites & 96 & 93 & $3 / 1$ & $<1$ & $(\mathrm{CD} 19+\mathrm{CD} 20)+/ \mathrm{CD} 10+/ \lambda+$ & CM- & EB & FL \\
\hline 10 & $\mathrm{R}$ & FNA scapular lesion & 95 & 87 & $86 / 86$ & $<1$ & $(\mathrm{CD} 19+\mathrm{CD} 20)+/ \mathrm{CD} 10+/ \kappa+$ & $\mathrm{CM}+$ & ND & FL \\
\hline 11 & $\mathrm{~N}$ & FNA laterocervical lymph node & 94 & 99 & $58 / 25$ & 1 & $(\mathrm{CD} 19+\mathrm{CD} 20)+/ \mathrm{CD} 10+/$ Igs- & $\mathrm{CMi}$ & EB & FL \\
\hline 12 & $\mathrm{~N}$ & EUS-FNA hepatic lesion & 99 & 59 & $14 / 14$ & 1 & $(\mathrm{CD} 19+\mathrm{CD} 20)+/ \mathrm{CD} 5 / \kappa+$ & $\mathrm{CM}+$ & $\mathrm{BMB}$ & SLL \\
\hline 13 & $\mathrm{~N}$ & EUS-FNA hepatic hilum lymph node & 85 & 80 & $34 / 20$ & 1 & $(\mathrm{CD} 19+\mathrm{CD} 20)+/ \mathrm{CD} 5 / \kappa+$ & CMs & BMB & SLL \\
\hline 14 & $\mathrm{~N}$ & FNA laterocervical lymph node & 6 & 74 & $72 / 72$ & 1 & $(\mathrm{CD} 19+\mathrm{CD} 20)+/ \mathrm{CD} 10+/ \lambda+$ & $\mathrm{CM}-$ & $\mathrm{EB}$ & PTLD \\
\hline 15 & $\mathrm{R}$ & FNA laterocervical lymph node & 60 & 37 & $38 / 38$ & 1.3 & $(\mathrm{CD} 19+\mathrm{CD} 20)+/ \kappa+$ & $\mathrm{CM}+$ & ND & DLBCL \\
\hline 16 & $\mathrm{~N}$ & FNA breast & 58 & 98 & $23 / 1$ & 1.9 & $(\mathrm{CD} 19+\mathrm{CD} 20)+/ \mathrm{Igs}-$ & $\mathrm{CM}+$ & $\mathrm{EB}$ & DLBCL \\
\hline 17 & $\mathrm{R}$ & EUS-FNA perigastric lymph node & 94 & 96 & $63 / 63$ & 1.7 & $(\mathrm{CD} 19+\mathrm{CD} 20)+/ \mathrm{CD} 5+/ \lambda+$ & $\mathrm{CM}+$ & FISH & MCL \\
\hline 18 & $\mathrm{R}$ & FNA axillary lymph node & 45 & 82 & $62 / 62$ & 1.2 & $(\mathrm{CD} 19+\mathrm{CD} 20)+/ \mathrm{CD} 5+/ \kappa+$ & $\mathrm{CM}+$ & $\mathrm{ND}$ & SLL \\
\hline 19 & $\mathrm{R}$ & FNA laterocervical lymph node & 49 & 94 & $22 / 22$ & 1 & $(\mathrm{CD} 19+\mathrm{CD} 20)+/ \mathrm{CD} 10+/ \kappa+$ & $\mathrm{CM}+$ & ND & FL \\
\hline 20 & $\mathrm{R}$ & FNA rectum lymph node & 88 & 99 & $28 / 11$ & 1 & $(\mathrm{CD} 19+\mathrm{CD} 20)+/ \mathrm{CD} 10+/ \lambda+$ & $\mathrm{CM}+$ & ND & FL \\
\hline 21 & $\mathrm{R}$ & FNA liver & 59 & 94 & $91 / 91$ & 1.5 & $(\mathrm{CD} 19+\mathrm{CD} 20)+/ \mathrm{CD} 10+/ \kappa+$ & $\mathrm{CM}+$ & ND & DLBCL \\
\hline 22 & $\mathrm{R}$ & Pleural fluid & 61 & 98 & $26 / 26$ & $<1$ & $(\mathrm{CD} 19+\mathrm{CD} 20)+/ \mathrm{CD} 5 / \kappa+$ & $\mathrm{CM}+$ & $\mathrm{ND}$ & LPL \\
\hline 23 & $\mathrm{~N}$ & FNA submandibular & 35 & 90 & $70 / 70$ & 1.5 & $(\mathrm{CD} 19+\mathrm{CD} 20)+/ \mathrm{CD} 5 / \kappa+$ & CMs & $\mathrm{EB}$ & DLBCL \\
\hline 24 & $\mathrm{R}$ & Ascites & 21 & 67 & $47 / 47$ & 1.4 & $(\mathrm{CD} 19+\mathrm{CD} 20)+/ \kappa+$ & $\mathrm{CM}+$ & ND & DLBCL \\
\hline 25 & $\mathrm{~N}$ & FNA thyroid & 63 & 98 & $97 / 97$ & 1.8 & $(\mathrm{CD} 19+\mathrm{CD} 20)+/ \mathrm{CD} 10+/$ Igs- & $\mathrm{CM}+$ & $\mathrm{EB}$ & $\mathrm{BL}$ \\
\hline 26 & $\mathrm{~N}$ & Pleural fluid & 68 & 83 & $26 / 26$ & $<1$ & $(\mathrm{CD} 19+\mathrm{CD} 20)+/ \kappa+$ & $\mathrm{CM}-$ & $\mathrm{BMB}$ & MZL \\
\hline 27 & $\mathrm{~N}$ & FNA rectum lesion & 83 & 97 & $5 / 2.5$ & 1 & $(\mathrm{CD} 19+\mathrm{CD} 20)+/ \kappa+$ & $\mathrm{CM}-$ & $\mathrm{EB}$ & MZL \\
\hline 28 & $\mathrm{R}$ & FNA paravertebral lesion & 88 & 99 & $81 / 81$ & $<1$ & $(\mathrm{CD} 19+\mathrm{CD} 20)+/ \lambda+$ & $\mathrm{CM}+$ & ND & FL \\
\hline 29 & $\mathrm{R}$ & FNA lung & 87 & 19 & $15 / 12$ & 1.1 & $(\mathrm{CD} 19+\mathrm{CD} 20)+/$ Igs - & $\mathrm{CM}+$ & ND & $\mathrm{FL}$ \\
\hline 30 & $\mathrm{R}$ & Pericardial fluid & 79 & 78 & $6.5 / 6.5$ & 1.1 & $(\mathrm{CD} 19+\mathrm{CD} 20)+/ \lambda+$ & $\mathrm{CM}-$ & ND & DLBCL \\
\hline
\end{tabular}

$\mathrm{BL}=$ Burkitt lymphoma; $\mathrm{BMB}=$ bone marrow biopsy; $\mathrm{CM}+=$ cytomorphology positive for lymphoma; CM- = cytomorphology negative for lymphoma; CMs = suspicious cytomorphology; $\mathrm{CMi}=$ inconclusive cytomorphology; $\mathrm{EB}=$ excisional biopsy; FL = follicular lymphoma; LPL = lymphoplasmacytic lymphoma; MALT = extranodal marginal zone lymphoma of mucosa-associated lymphoid tissue; $\mathrm{MZL}=$ marginal zone lymphoma; $\mathrm{N}$ = newly diagnosed; $\mathrm{ND}=$ not done; $\mathrm{PTLD}=$ posttransplant lymphoproliferative disorder; $\mathrm{R}=$ relapse; SLL = small lymphocytic lymphoma; TCRBCL $=$ T-cell-rich B-cell lymphoma.

phoid aggregate in chronically inflamed mucosa, not suggestive of lymphoma involvement. Sample 11 was hematic and was considered insufficient for a diagnostic conclusion. Sample 27 displayed a heterogeneous pattern of small to medium lymphocytes without significant morphologic alterations. SCE specimens No. 9, 26, and 30 were all considered negative by $\mathrm{CM}$, being composed of a heterogeneous pattern of lymphocytes, inflammatory cells, and reactive mesothelial cells.
The absence of an altered immunophenotype was observed in 72 out of 103 (70\%) samples, including $42 \mathrm{~B} / \mathrm{R}$ cases and 21 specimens in which a Ca was detected by $\mathrm{CM}$, confirmed by a subsequent surgical biopsy in 13 out of 42 and 15 out of 27 cases, respectively. The FSr value of $B$ cells was, in these cases, always $\leq 1.1$. As expected, no immunophenotypic abnormalities were detected by FC in 3 cases of HL. 


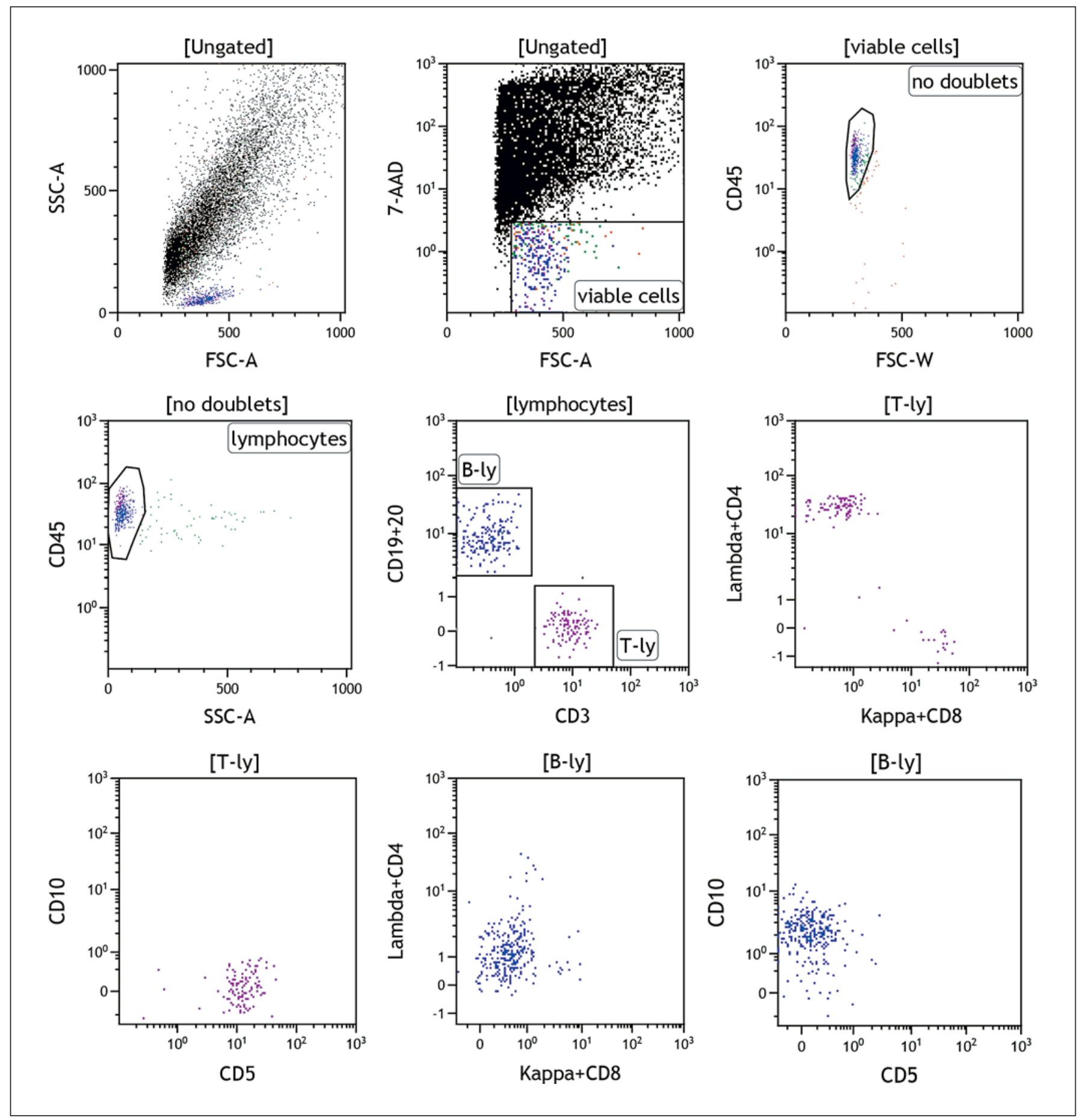

Fig. 3. Example of the STA and gating strategy applied to an FNA sample (case 14) with a high number of dead cells. The STA and gating strategy described in figure 1 allowed the detection of a small number of viable CD $10^{+} \lambda \mathrm{B}$ cells. FSC-A = Forward-scatter area; FSC$\mathrm{W}=$ forward-scatter width; SSC-A = side-scatter area. 


\section{Discussion}

One of the factors that hamper immunophenotyping investigations in FNA and body fluids is the low number of cells that can be processed. Therefore, the set-up of a single tube, based on patient information and clinical suspicion, is frequent in FC laboratory practice. In this study, we report our experience with an FC assay that was developed in order to gather the greatest amount of information from hypocellular samples sent for lymphoma suspicion or monitoring [11]. The method used different MoAbs cocktailed in one tube to detect and identify lymphocytes, as well as a logical gating strategy to gate out dead cells and get rid of debris and clumped cells (doublets). We have already used a similar approach to detect occult lymphoma cells in cerebrospinal fluid with good results [14].

Multicolor FC evaluation of a single tube for paucicellular samples has been previously proposed by others in the literature [15-18]. Langerak et al. [15], using 8-color labelling (small sample tube) for screening of lymphomas, detected 13 positive cases in a cohort of 164 small cell samples consisting of cerebrospinal fluid and vitreous biopsies. Preijers et al. [16] proposed a 10-color panel to detect leukemia and lymphoma cells in small cell samples, but they did not report data on specimen types.

Rajab and Porwit [17] and Rajab et al. [18] developed a 10-color 14-antibody tube for screening of abnormal lymphoid populations and myelodysplasia in bone marrow samples, which was also reported to be useful in the evaluation of paucicellular cytologic specimens $[17,18]$. None of these studies included a vital dye in the protocol.

Our study was mainly done on specimens like FNA and EUS-FNA, which may contain high amounts of debris, dead cells, or aggregates, particularly if coming from extranodal sites (39\% of the samples in this study). Debris may originate from the damage and disintegration of cells following apoptosis or fragmentation associated with FNA and body fluid aspiration procedures, even if they are minimally invasive. Dead cells may be the result of cell fragility and necrosis that may occur in neoplastic cells. Aggregates may derive from the presence of nonhemopoietic cells. All of these aspects could affect the overall quality of the specimens and the result of the FC analysis, and then adequate gating strategies must be applied in order to remove unwanted events [11]. A viability dye and a doublet discrimination gate were introduced for these reasons into the assay. In this way, we were able to obtain meaningful results also in samples with a viability $<50 \%$, usually discarded for FC investigations; an exam- ple is showed in figure 3. Using the STA, we detected NHL of the mature B-cell type in 31 samples; 7 had a viability $<50 \%$. In these cases, CD19 and CD20 allowed the identification of B cells; $\kappa$ and $\lambda$ allowed the detection of clonally restricted B cells (fig. 1); CD5 and CD10 allowed either subtyping of lymphomas or the detection of neoplastic cells in cases where clonal restriction was not evident, as neoplastic cells were mingled with normal B cells (fig. 2). The calculation of FSr gave a reliable estimation of B-cell size in all but one case, i.e. pericardial fluid in a patient with high-grade lymphoma in the pharynx. The neoplastic population described in the histologic report consisted of a mixture of medium to large cells. We cannot exclude that delays in delivery or improper conservation may have affected the cell size in this sample. On the other hand, we could hypothesize that medium-sized neoplastic cells selectively colonized the pericardial serous cavity in this patient.

Using the STA, we detected lymphomatous cells in 8 samples in which CM gave a negative or inconclusive result and in 2 cases considered only suspicious. Difficulties in morphologic detection of lymphomas in FNA and EUS-FNA may be related to sampling errors, tissue necrosis, a scarcity of tumor cells, a loss of tissue architecture, and difficulties in recognition of malignancy due to a morphologic overlap between neoplastic and nonneoplastic lymphocytes [19]. Analogously, in SCE morphologic distinction between reactive and malignant cells can be difficult in cases of hypocellular and bloody specimens, or if malignant cells are sparse, so that even experienced cytomorphologists are unable to render a conclusive diagnosis [20,21].

In this study, FC excluded a neoplastic lymphoproliferative process in 69 cases in which no evidence of monotypical B cells or atypical T cells was found. FC has been proven to be of great value when there is a diagnostic dilemma between a hematologic and a reactive or inflammatory condition in which the lymphocyte infiltrate mimics lymphoma $[22,23]$. Small round blue neoplasms such as neuroendocrine tumors or poorly differentiated $\mathrm{Ca}$ and melanoma may be another diagnostic dilemma in which FC can contribute to a differential diagnosis towards lymphomas $[24,25]$. The presence of CD45-negative elements of nonhematopoietic origin was signaled by $\mathrm{FC}$ in 5 patients who received a final diagnosis of $\mathrm{Ca}$. The emerging role of $\mathrm{FC}$ for screening of $\mathrm{Ca}$ metastasis has been recently evidenced [26], but that is beyond the scope of this study.

We did not attempt to detect Reed-Sternberg cells by FC. It must be noted, however, that cases with a final di- 
agnosis of HL had a prevalence of the $\mathrm{CD} 4^{+} \mathrm{T}$-cell subset; this findings has been previously reported to be highly suggestive of this type of lymphoma [27].

Optimization of FNA collection techniques, submission of larger volumes of body fluids, and a fast specimen delivery may contribute to reducing the number of paucicellular samples. The results here presented are evidence of the efficacy of the STA approach for the detection of neoplastic cells in paucicellular samples, also when these are of poor quality. The STA was able to detect or exclude NHL in hypocellular samples by using different antibody cocktails and different instrumentations and software for the analysis. Using the described approach, we have demonstrated that, even in the case of specimens usually considered inadequate for FC analysis, appropriate sample processing, gating strategies, and multicolor protocols can help to reduce false-negative or nondiagnostic cases in the workup of lymphomas. The increase in the number of fluorescence channels available for immunophenotyping and the use of targeted antibodies will further improve the detection of hematologic malignancies, as well as their follow-up and monitoring.

\section{Acknowledgments}

The authors thank A. Di Tomasso, S. Monticone, and O. Gaiola for their invaluable and excellent technical assistance.

\section{Disclosure Statement}

The authors have no conflicts of interests to declare.

\section{References}

1 Zeppa P, Marino G, Troncone G, Fulciniti F, De Renzo A, Picardi M, Benincasa G, Rotoli B, Vetrani A, Palombini L: Fine-needle cytology and flow cytometry immunophenotyping and subclassification of non-Hodgkin lymphoma: a critical review of 307 cases with technical suggestions. Cancer 2004;102:5565.

-2 Barrena S, Almeida J, Del Carmen GarcíaMacias M, López A, Rasillo A, Sayagués JM, Rivas RA, Gutiérrez ML, Ciudad J, Flores T, Balanzategui A, Caballero MD, Orfao A: Flow cytometry immunophenotyping of fine-needle aspiration specimens: utility in the diagnosis and classification of non-Hodgkin lymphomas. Histopathology 2011;58:906-918.

-3 Savage EC, Vanderheyden AD, Bell AM, Syrbu SI, Jensen CS: Independent diagnostic accuracy of flow cytometry obtained from fineneedle aspirates: a 10-year experience with 451 cases. Am J Clin Pathol 2011;135:304309.

4 Demurtas A, Accinelli G, Pacchioni D, Godio L, Novero D, Bussolati G, Palestro G, Papotti M, Stacchini A: Utility of flow cytometry immunophenotyping in fine-needle aspirate cytologic diagnosis of non-Hodgkin lymphoma: a series of 252 cases and review of the literature. Appl Immunohistochem Mol Morphol 2010;18:311-322.

-5 Stacchini A, Carucci P, Pacchioni D, Accinelli G, Demurtas A, Aliberti S, Bosco M, Bruno M, Balbo Mussetto A, Rizzetto M, Bussolati G, De Angelis C: Diagnosis of deep-seated lymphomas by endoscopic ultrasound-guided fine needle aspiration combined with flow cytometry. Cytopathology 2012;23:50-56.
Quijano S, López A, Manuel Sancho J, Panizo C, Debén G, Castilla C, Antonio García-Vela J, Salar A, Alonso-Vence N, González-Barca E, Peñalver FJ, Plaza-Villa J, Morado M, García-Marco J, Arias J, Briones J, Ferrer S, Capote J, Nicolás C, Orfao A; Spanish Group for the Study of CNS Disease in NHL: Identification of leptomeningeal disease in aggressive B-cell non-Hodgkin's lymphoma: improved sensitivity of flow cytometry. J Clin Oncol 2009;27:1462-1469.

-7 Missotten T, Tielemans D, Bromberg JE, van Hagen PM, van Lochem EG, van Dongen JJ, Baarsma GS, Langerak AW: Multicolor flow cytometric immunophenotyping is a valuable tool for detection of intraocular lymphoma. Ophthalmology 2013;120:991-996.

-8 Iqbal J, Liu T, Mapow B, Swami VK, Hou JS: Importance of flow cytometric analysis of serous effusions in the diagnosis of hematopoietic neoplasms in patients with prior hematopoietic malignancies. Anal Quant Cytol Histol 2010;32:161-165.

-9 Cesana C, Klersy C, Scarpati B, Brando B, Volpato E, Bertani G, Faleri M, Nosari A, Cantoni S, Ferri U, Scampini L, Barba C, Lando G, Morra E, Cairoli R: Flow cytometry vs cytomorphology for the detection of hematologic malignancy in body cavity fluids. Leuk Res 2010;34:1027-1034.

10 Shen H, Tang Y, Xu X, Wang L, Wang Q, Xu W, Song H, Zhao Z, Wang J: Rapid detection of neoplastic cells in serous cavity effusions in children with flow cytometry immunophenotyping. Leuk Lymphoma 2012;53:1509-1514. $\checkmark 11$ Stacchini A, Demurtas A, Aliberti S: Immunophenotyping of paucicellular samples. Curr Protoc Cytom 2014;68:9.46.1-9.46.14.
12 Zembruski NC, Stache V, Haefeli WE, Weiss J: 7-Aminoactinomycin D for apoptosis staining in flow cytometry. Anal Biochem 2012; 429:79-81.

13 Craig FE, Foon KA: Flow cytometric immunophenotyping for hematologic neoplasms. Blood 2008;111:3941-3967.

14 Stacchini A, Aliberti S, Demurtas A, Benevolo G, Godio L: Ten antibodies, six colors, twelve parameters: a multiparameter flow cytometric approach to evaluate leptomeningeal disease in B-cell non-Hodgkin's lymphomas. Cytometry B Clin Cytom 2012;82:139-144.

-15 van Dongen JJ, et al; EuroFlow Consortium (EU-FP6, LSHB-CT-2006-018708): EuroFlow antibody panels for standardized n-dimensional flow cytometric immunophenotyping of normal, reactive and malignant leukocytes. Leukemia 2012;26:1922-1925.

-16 Preijers FW, Huys E, Moshaver B: OMIP-010: a new 10-color monoclonal antibody panel for polychromatic immunophenotyping of small hematopoietic cell samples. Cytometry A 2012;81:453-455.

17 Rajab A, Porwit A: Screening bone marrow samples for abnormal lymphoid populations and myelodysplasia-related features with one 10-color 14-antibody screening tube. Cytometry B Clin Cytom 2015;88:253-260.

18 Rajab A, Boerner S, da Cunha Santos G, Geddie W, Ko H, Porwit A: Ten-color 14 antibody flow cytometry panel for immunophenotyping of paucicellular cytologic specimens. Cytometry B Clin Cytom 2013;84:419.

19 Schwock J, Geddie WR: Diagnosis of B-cell non-Hodgkin lymphomas with small-/intermediate-sized cells in cytopathology. Patholog Res Int 2012;2012:164934. 
20 Alexandrakis MG, Passam FH, Kyriakou DS, Bouros D: Pleural effusions in hematologic malignancies. Chest 2004;125:1546-1555.

21 Pillai V, Cibas ES, Dorfman DM: A simplified flow cytometric immunophenotyping procedure for the diagnosis of effusions caused by epithelial malignancies. Am J Clin Pathol 2013;139:672-678.

22 Stacchini A, Aliberti S, Pacchioni D, Demurtas A, Isolato G, Gazzera C, Veltri A, Maletta F, Molinaro L, Novero D: Flow cytometry significantly improves the diagnostic value of fine needle aspiration cytology of lymphoproliferative lesions of salivary glands. Cytopathology 2014;25:231-240.
23 Stacchini A, Pacchioni D, Demurtas A, Aliberti S, Cassenti A, Isolato G, Gazzera C, Veltri A, Sapino A, Papotti M, Freddi M, Palestini N, Sisto G, Novero D: Utilility of flow cytometry as ancillary study to improve the cytologic diagnosis of thyroid lymphomas. Cytometry B Clin Cytom 2015;88:320-329.

24 Meis-Kindblom JM, Stenman G, Kindblom LG: Differential diagnosis of small round cell tumors. Semin Diagn Pathol 1996;13:213241.
Bynum JP, Duffield A, Ali SZ: Impact of flow cytometry in liver cytopathology. Acta Cytol 2015;59:51-60.

26 Acosta M, Pereira J, Arroz M: Screening of carcinoma metastasis by flow cytometry: a study of 238 cases. Cytometry B Clin Cytom 2016;90:289-294.

27 Hudnall SD, Betancourt E, Barnhart E, Patel J: Comparative flow immunophenotypic features of the inflammatory infiltrates of Hodgkin lymphoma and lymphoid hyperplasia. Cytometry B Clin Cytom 2008;74:1-8. 